UDC 81 ' 42

DOI https://doi.org/10.32841/2409-1154.2020.46-2.20

\author{
Pronina H. M., \\ Candidate of Philological Sciences, \\ Associate Professor at the Department of Translation and Foreign Languages \\ National Metallurgical Academy of Ukraine
}

\author{
Abramova O. O., \\ Candidate of Philological Sciences, \\ Associate Professor at the Department of Translation and Foreign Languages \\ National Metallurgical Academy of Ukraine
}

\title{
PRODUCTIVE MEANS OF WORD-FORMATION IN THE MODERN LANGUAGE OF AMERICAN SOCIAL WEBS, INTERNET PLATFORM YOUTUBE AND MESSENGERS
}

Summary. The paper investigates the problems of word-formation in the language of American social networks, video-sharing platform YouTube and messengers. In spite of the existing studies devoted to the morphological nature of neologisms used by teenagers in social networks, the tendencies in word formation in social media, etc., the words derived from the names of the popular social networks and platforms/messengers (Facebook, Instagram, YouTube, Twitter, LinkedIn, Pinterest, Reddit, WhatsApp) have not been subjected to a thorough analysis and require further investigation. Thus, the authors analyse the lexical units which have recently been formed from the names of the popular social networks and Internet platform/messengers. While studying it was found out that conversion as well as derivation appear to be the most productive means of neologism formation in such specific and pooular sphere of modern communication as social networks and the like. In the paper the derivate under analyses have been divided into three semantic categories. The first one denotes the process of using social networks, video-sharing platform YouTube and messengers. This category comprises verbs derived from nouns (proper names) and their non-finite forms - gerunds and participles. The second semantic group includes the nouns used to denote users of this or that social network, Internet platform/messengers. Mostly nouns of this group are derived from the proper name of the social network or Internet platform/messenger by means of the suffixation. The word-forming models created by means of the productive suffixes -er/-or to designate the users of the networks/platform/messenger (Instagrammer, Facebooker, Youtuber, Twitterer, Linkediner, Redditor etc.) have been singled out. The cases of utilising other suffixes, such as $-i s t a$, $-e e$ or $-i$, are less frequent. The third semantic group comprises the adjectives derived from the nouns - proper names of social networks according to the model "noun+able" (Facebookable, Instagramable).

Key words: word-formation, conversion, derivation, zero derivation, affixation.

Problem statement. Constant development of the English language reflects every little change that occurs in the new culture generated by the Internet communication on various social networks, which results in new vocabulary units appearing and functioning in international context. Thus, the means of word-formation in the language of American social webs, video-sharing platform and mes- sengers are to be investigated in order to understand the morphological nature of newly appeared words.

Analysis of recent research and publications. Analysis has shown, that there are few studies on the morphological nature of neologisms used by teenagers in social networks (S. Shahlee and R. Mustaffa, 2019), the formation patterns of social media terminilogy (A. Kilyenia, 2015), blending words in social media (G. Giyatmi, R. Wijayava and S. Arumi, 2017), and the tendencies in word formation among teenagers in social media (D. Ljubotenska, 2018). However, the words derived from the names of the popular social networks, video-sharing platform YouTube and messengers have not been subjected to a thorough analysis and require investigation.

The aim of the paper is to investigate the words denoting the constituents of the social networks, video-sharing platform YouTube and messengers functioning, particularly those which have recently entered the English language by means of conversing the already existing lexical units (the names of the popular social networks, etc.) as well as by means of derivation (affixation).

Using the continuous sampling method we have selected the study material from the open Internet resourses.

Presentation main material. Nowadays, Internet becomes more and more popular around the world, especially taking into consideration the repeated lockdowns caused by Coronavirus which changed our reality greatly. The number of Internet users is constantly growing in different parts of the world as compared with those in 2018 and 2019. According to Internet World Stats, there are more than 4.5 billion people connected to the Internet all over the world that is about 59 percent of the total global population, while in 2018 it was about 2.6 and in $2019-3.5$ billion respectively [7]. The USA is among leaders in the Internet communication. The most popular social networks, platforms and messengers in the USA are YouTube, Facebook, Instagram, Pinterest, LinkedIn, Snapchat, Twitter, WhatsApp and Reddit [14]. These networks are known all over the world, their names gave birth to a great number of derivatives. The latter became quite popular with Internet users. The language of social networks, etc. has its peculiarities which are caused by the limitations of space as well as the specific conditions of Internet communication. The formation of new Internet terms from the names of the social networks, YouTube and messengers 
seems quite productive because it facilitates their understanding by a great number of people from all over the world.

In the study, we propose to divide the derivate into several semantic categories which are common for most social networks, etc. The first one denotes the very process of using social networks or Internet platform/messengers. This category comprises mostly verbs and their non-finite forms - gerunds and participles. The verbs of this category are formed by means of conversion from the names of the corresponding social networks. Conversion is an affixless derivation consisting in making a new word from some existing word by changing the category of a part of speech, the morphemic shape of the original word remaining unchanged [1, p. 68]. Conversion appears to be one of the most productive means of word-formation. Linguists admit "the regularity and the completeness with which converted units develop a paradigm of their new category of part of speech. As soon as it has crossed the category borderline, the new word automatically requires all the properties of the new category, so that if it has entered the verb category, it is now regularly used in all the forms of tense, and it also develops the forms of the participle and the gerund" [1, p. 69]. Let us consider the examples reflecting these processes.

To start with, the noun Facebook, which is a proper name of the American social networking service, became a source for the creation of a new verb with three meanings - "to send someone a message on Facebook", "to publish information on Facebook" and "to spend time using Facebook", for example: "I facebooked him and he told me where he lived on campus" [4]. On the BBC website there is a resource for listening based on the article "Keep your English up-to-date Facebook" by G. Dudeney. The author provides such bright examples of using the verb facebook in the meanings "to upload something on the Internet" ("I've just facebooked the photos from my summer holiday"), "to find a person on Facebook" ("I facebooked that guy John and it turns out he's an architecht"), "to contact a person" ("Did you facebook Susan about the party?") [18].

Furthermore, the gerund facebooking was created from the verb to facebook: "As Facebook use continues to be an integral part of people's everyday life, enriching our understanding of the impact of Facebooking on its users will better inform researchers and the lay public alike about the psychological impact of using Facebook" [5].

Another vivid example of forming a verb from a noun, and then a gerund from this verb has appeared from a world-wide known proper name of the social network Instagram. For instance, one of the articles in the New York Times is titled as follows: "Should Any Parents Be Instagramming Their Kids?" [21], where we can observe the verb to Instagram used in the Present Continuous Infinitive form. The gerund Instagramming is also quite common for the modern English language: Check out the first article in our Instagramming your Trip series, which will take you through tips and tricks on making your subject look good in photographs! [2]; Whilst I can't cover everything, I can give you general guidelines in the Art of Instagramming like a Boss [17]; The Top Frustrating Problems with Instagramming for Business - And How to Fix Them! [20].

Being a proper name of the American video-sharing platform, the noun YouTube has also provided the basis for the verb formation meaning the following actions (according to Macmillan Dictionary): "to upload a video to the videosharing service YouTube" (e.g.
The footage has amassed nearly a million views since it was youtubed earlier this week) and "to find something on video-sharing website YouTube" (e.g. I youtubed Oxford University lectures) [8]. The verb to youtube was later transformed into a Gerund: Is It Too Late to Start Blogging, Youtubing or Instagramming in 2020? [8].

However, the Participle II "youtubed" formed from the verb "to youtube" has a somewhat negative coloring. It means "the process by which you intend to go onto YouTube to look up and watch one or two videos but to end up following the links for hours and hours" [24]. It is often used in the pattern "to get+youtubed": "I'm sorry baby I meant to call you 2 hours ago but I got "YouTubed" [24].

The verb to pinterest, indicating "the action of repining a post on Pinterest" [24] has been created by means of conversion from the noun Pinterest - the proper name of another social network: Did you see those tutorials I Pinterested yesterday on how to crochet with dog fur?; I should have Pinterested that link because I can't remember what it was now [24].

Sometimes participles can be formed from the verbs that were originated from nouns. Thus, the noun Pinterest is a source for the Participle II pinterested, used in the situations when "you're too distracted by Pinterest to be bothered by anything else" [24]: "Hey come look at this!" "Nope, too Pinterested" [24].

WhatsApp messenger is very popular among Hispanics in the US. The verb "to whatsapp" means "to communicate with somebody using the social media app, WhatsApp": "Could you please whatsapp me pictures of the party scene?" [12]. Thus, when you "send the message through WhatsApp to him", it may be rendered as "you are whatsapping him" [24]. Here we have an example of Participle I formation from the verb "to whatsapp".

Snapchatting is "the verb form of using the application Snapchat" (a messenger): "Stop taking selfies! Don't you have enough pictures of yourself?" - "I'm not, I'm snapchatting” [24].

The verb "to twitter" may be used to denote the process of "writing a message on twitter" as in the example: "Wait a second! I'm twittering" [24]. Nevertheless, the proper verb for the process of Twitter usage is "to tweet". In Cambridge Dictionary it is defined as "to publish a short remark or piece of information on Twitter": "He tweeted that he was just about to meet the president" [4] or "to communicate on Twitter using quick short messages": "Many famous people tweet regularly" [4]. Here the polysemantic word acquires new meaning based on the phonetic motivation. The sounds of tweet publication are similar to those produced by the birds.

The second semantic group which has high frequency of usage in the Internet communication is the nouns used to denote people who use this or that social network/video-sharing platform/ messenger. Mostly nouns of this group are derived from the name of the Internet platform by means of the suffixation, generally by suffix -er/-or. Nevertheless, there are some cases when other suffixes such as -ista, -ee or - $i$ are used.

Instagram + -er $\rightarrow$ Instagrammer, meaning "someone who regularly shares images, or other things such as video or text, on the social media service Instagram" [4]: What Kind Of Instagrammer Are You? [22]; Pro-Shot: Food Photography for the Blogger and Instagrammer: Learn to Shoot and Edit Photos on Your Smartphone for Tasty Results That Get Noticed! [10]; If you're planning a trip to London, here are 10 top London Instagrammers to follow [4].

YouTube + -er $\rightarrow$ YouTuber - "a person who often uses the website YouTube, especially someone who makes 
and appears in videos on the website" [4]: Forgot about becoming an astronaut-these days, kids are three times more likely to dream of becoming a professional YouTuber [24]; Here's a list of the most subscribed YouTubers and channels on the platform; It's also become a platform for YouTubers to become superstars in their own right [3].

Facebook + -er $\rightarrow$ Facebooker. The derived word means "someone who uses the social networking site Facebook on a regular basis" [12]: If you're a Facebooker who's lusting after the Apple $i P a d$... then chances are you're aged between 18 and 25 and have an interest in popular culture ... [12]; Within hours, I had nearly 150 bloggers, Tweeters, and Facebookers volunteering to participate [13]. At the same time there are those who are addicted to Facebook. On the contrary to the first group of people such fans of Facebook are called "facebookee": "Check back again, you facebookee!" [24].

Snapchat + -er $\rightarrow$ Snapchatter. This is "a user of the mobile photo messaging application Snapchat": "What kind of snapchatter are you?" [23].

Twitter + -er $\rightarrow$ Twitterer, meaning "a person who uses Twitter": She is anything but a twitterer, though - it is the warmth of the voice that makes it truly heavenly [13]. Moreover, people who are addicted to Twitter, "who use Twitter a lot" are called twitterati: "The twiterrati were able to communicate news on the subject" [4].

LinkedIn + -er $\rightarrow$ LinkedIner. LinkedIners are called those "who joined the Linkedin social connection network LinkedIn": "I just submitted another post for all my fellow Linkerdiners to "like" [24]. "Linkediners" are quite often used as addressing to the members of the network: "Dear Linkediners, thank you, muchas gracias, grazie molte!" [16] or "Dear Linkediners, may I have your attention please..." [11].

Reddit + -er $\rightarrow$ Redditor. The lexical unit "redditor" has a somewhat negative connotation because it means "an introverted and emojiphobic person who spends way too much time on Reddit to gain virtual Internet points because they can't get a girlfriend": "Redditors hate reports and will call other Redditors out on it, then they will go post a repost themselves" [24].

Pinterista is a derivate from Pinterest which is based upon the analogy of building nouns in Spanish or Italian. Hence, in the below examples one may see the ending "-istos" which is analogous to Spanish ending indicating males. Pinterista means "a fabulous person who is devoted to the online pin board called Pinterest" or "a fabulous person who believes in the power of Pinterest": "Only Pinteristos know how to pin"; "I'm a Pinterista since I learned how to make a tutu on Pinterest" [24].

The third semantic group comprises the adjectives derived from the names of social networks and video-sharing platform YouTube. They are mainly derived according to the model "noun + -able". This became possible due to "the flexibility of the English vocabulary system that makes a word formed by conversion capable of further derivation, so that it enters into combinations not only with functional but also with derivational affixes characteristic of a verbal stem, and becomes distributionally equivalent to it" [1, p. 71].

The derivative Instagrammable, meaning "attractive or interesting enough to be suitable for photographing and posting on the social media service Instagram" [4], is formed by means of adding the suffix -able to the noun Instagram: World's most Instagrammable spots: Find the best location for Instagram pho- tos in every city and country [6]; Looking for the most Instagrammable places in London? I've chosen 35 cool spots in my hometown that are guaranteed to blow up your feed [18]. Moreover, the hashtag \#instagrammable refers to 258553 publications on the Instagram.

The same word-forming model is observed in the word Facebookable, that is used in the meaning of "Worthy of a Facebook post" and "Appropriate enough to be seen online, especially on Facebook" [19]: Here's a totally Facebookable idea: putting a propeller like this on a golf cart [19]; You know it was a good night when only 3 out of 152 pics are facebookable [24].

Twitterable are called those "things which are worthy of being put on Twitter": "I just had the most awkward run in with my ex. This is totally twitterable!" [24].

The suffix -able can also be found in the lexical unit "YouTubeable" which has the following meanings: "A video that is able to be uploaded to YouTube", "A video worthy of being uploaded to YouTube, "A video that can be found on YouTube". As examples the following sentences can be considered: "Ijust took some digital video of the dog doing a deuce. Is it YouTubeable?"; This show is just too old to be YouTubeable" [24].

The adjective Pinterestable is used "when you like something you've seen on Pinterest and want to pin it on a board you have": "This craft project is pinterestable" [24].

The adjective snapchatable has a somewhat different meaning. It denotes something "worthy of a snapchat, can be used as a "snapchatable time" meaning that the people involved are having an interesting time, worthy of sharing with others through video": "It looks like they're having a snapchatable time" [24].

At the same time, the model "noun + -ing" appears to be less frequent when it comes to the formation of adjectives, for instance Pinterest + -ing $\rightarrow$ pinteresting used to refer to the situations "when a Pinterest pin piques ones interest": Wow that's very pinteresting! [24]. It is obvious that this adjective is formed analogously to the adjective "interesting". Just the same principle was used while forming the adjectives "pinterested" and "not pinterested".

Conclusions. In the study, we propose to divide the derivate into several semantic categories which are common for most social networks/video-sharing platform/messengers. The first one denotes "the process of using this or that Internet platform". This category comprises mostly verbs and their non-finite forms - gerunds and participles. The verbs of this category are formed by means of conversion from the names of the corresponding social networks, etc. The second semantic group which has high frequency of usage in the Internet communication is the nouns used to denote people who use this or that social network. Mostly nouns of this group are derived from the names of the social webs/Internet platform/ messengers by means of the suffixation, generally by suffix -er/-or. Nevertheless, there are some cases when other suffixes such as -ista, -ee or $-i$ are used. The third semantic group comprises the adjectives derived from the names of social networks. They are mainly derived according to the model "noun + -able". So, the study of neologisms in such important part of people life as Internet communication has showed that newly formed words are often produced by conversion and derivation on the basis of the names of already existing social networks. The Internet users who are number ones in the process of creating neologisms try to facilitate understanding of new lexical units and therefore in most cases imitate the patterns of the ordinary words formation. 
The means of word-formation in the modern language of American social webs/YouTube/messengers requires further study due to the fact, that new social networks and Internet platforms/messengers are inevitably going to appear in the future, thus, becoming a source for creating new lexical units.

\section{References:}

1. Ніколенко А.Г. Лексикологія англійської мови - теорія і практика. Вінниця : Нова Книга, 2007. 528 с.

2. A Complete Guide to Instagramming your Trip. URL: https://www. travelex.com.au/travelex-hub/travel-tips/instagramming-your-triplooking-good-in-photos.

3. Boyd J. The Most-Subscribed YouTubers and Channels URL: https:// www.brandwatch.com/blog/most-subscribed-youtubers-channels.

4. Cambridge Dictionary. URL: https://dictionary.cambridge.org.

5. Hu X., Kim A., Siwek N., Wilder D. The Facebook Paradox: Effects of Facebooking on Individuals' Social Relationships and Psychological Well-Being. URL: https://www.ncbi.nlm.nih.gov/pmc/articles/ PMC5281564.

6. Instagrammable Spot. URL: https://bigseventravel.com/category/ instagrammable-spots.

7. Internet World Stats. URL: https//www.Internetworldstats.com/stats.htm.

8. Is It Too Late to Start Blogging, Youtubing or Instagramming in 2020? URL: https://northabroad.com/is-it-too-late-to-start-bloggingyoutubing-or-instagramming-in-2020.

9. Keep your English up to Date. URL: https://www.bbc.co.uk/ worldservice/learningenglish/radio/specials/1720_uptodate4/page14. shtml.

10. Kerry M. Pro-Shot: Food Photography for the Blogger and Instagrammer: Learn to Shoot and Edit Photos on Your Smartphone for Tasty Results That Get Noticed! USA, 2020.120 p.

11. LinkedIn. URL: https://www.linkedin.com/pulse/dear-linkedinersmay-i-have-your-attention-please-lokesh-vishwakarma.

12. Macmillan Dictionary. URL: https://www.macmillandictionary.com/ dictionary/british.

13. Oxford English and Spanish Dictionary, Thesaurus, and Spanish to English Translator. URL: https://www.lexico.com/definition/ facebooker.

14. Perrin A., Anderson M. Share of U.S. adults using social media, including Facebook, is mostly unchanged since 2018. URL: https:// www.pewresearch.org/fact-tank/2019/04/10/share-of-u-s-adultsusing-social-media-including-facebook-is-mostly-unchangedsince-2018.

15. Reverso Context. URL: https://context/reverse.net/перевод английский-русский/tweet.

16. Scialpi D. Dear LinkedIners, thank you, muchas gracias, grazie molte! Economist. 2016, Jul. 18. URL: https://davidescialpi.medium.com/dearlinkediners-thank-you-muchas-gracias-grazie-molte-220400b73d62.

17. The Art of Instagramming Like a Boss. URL: https://www. the-entourage.com/blog/art-instagramming-like-boss.

18. The Most Instagrammable Places in London - 35 Photography Spots You Won't Want to Miss. URL: https://www.londonxlondon.com/ instagrammable-places-in-london.

19. The Rice University Neologisms Database. URL: https://neologisms. rice.edu/index.php? $\mathrm{a}=$ term $\& \mathrm{~d}=1 \& \mathrm{t}=20761$.
20. The Top Frustrating Problems with Instagramming for Business - And How to Fix Them! URL: https://neilpatel.com/blog/fix-instagramfrustrating-problems.

21. Weiner J. Should Any Parents Be Instagramming Their Kids? URL: https://www.nytimes.com/2020/06/16/opinion/myka-staufferchildren-social-media.html.

22. What Kind of Instagrammer are you? URL: https://www.tryinteract.com/ quiz/what-kind-of-instagrammer-are-you.

23. What Kind of Snapchatter are you? URL: https://mashable.com/ 2017/01/02/types-of-people-on-snapchat.

24. Who's the Most Popular YouTuber in Every Country? URL: https:// www.visualcapitalist.com/worlds-most-popular-youtubers.

25. Urban Dictionary. URL: https://www.urbandictionary.com.

Проніна Г. М., Абрамова О. В. Продуктивні засоби словотвору в сучасній мові американських соціальних мереж, інтернет-платформи YouTube та месенджерів

Анотація. Статтю присвячено дослідженню проблеми словотворення в мові американських соціальних мереж, відеохостингу YouTube та месенджерів. Незважаючи на невелику кількість наявних досліджень, присвячених морфологічній природі неологізмів, що використовуються підлітками в соціальних мережах, тенденціям до словотворення у соціальних мережах, слова, що походять від назв популярних соціальних мереж та інтернет-платформи або месенджерів (Facebook, Instagram, YouTube, Twitter, LinkedIn, Pinterest, Reddit) не поставали об'єктом вичерпного аналізу і вимагають подальшого вивчення. Таким чином, у статті проаналізовано слова, які нещодавно увійшли до англійської мови шляхом конверсії вже наявних лексичних одиниць (назв популярних соціальних мереж, інтернет-платформи та месенджерів), а також за допомогою деривації (афіксації). Нульова деривація, або конверсія, постає одним 3 найбільш продуктивних засобів утворення дієслів від іменників, які є джерелом творення герундія та дієприслівників. Аналізовані у статті похідні слова класифіковано на три семантичні категорії. Перша категорія слів використовується на позначення власне процесу використання соціальних мереж, інтернет-платформи та месенджерів. Ця категорія включає дієслова, утворені від іменників, що позначають власні назви, та їх неособові форми, такі як герундій та дієприкметник. До другої семантичної групи віднесено іменники, що використовуються на позначення користувачів соціальних мереж, YouTube, месенджерів. Іменники цієї групи походять від назв соціальних мереж або інтернет-платформи за допомогою суфіксації. Виділено словотвірні моделі, утворені за допомогою продуктивних суфіксів -er/-or на позначення користувачів мереж/платформи/месенджерів (Instagrammer, Facebooker, Youtuber, Twitterer, Linkediner, Redditor тощо). Випадки використання інших суфіксів, таких як -ista, -ee, $-i, \epsilon$ менш частотними. Третя семантична група включає прикметники, що походять від іменників, що позначають назви соціальних мереж, за моделлю «іменник + -able» (Facebookable, Instagramable).

Ключові слова: словотворення, конверсія, деривація, нульова деривація, афіксація. 